Олександр Томенко

Сумський державний педагогічний університет імені A. C. Макаренка ORCID ID 0000-0002-1097-965X

Сергій Матросов

Сумський державний педагогічний університет імені А. С. Макаренка ORCID ID 0000-0001-6980-1402

Олена Ярова

Медичний центр «Медея» ORCID ID 0000-0001-8550-0132 DOI 10.24139/2312-5993/2020.01/309-322

\title{
ОСОБЛИВОСТІ СЕКЦІЙНОЇ МОДЕЛІ ОРГАНІЗАЦІЇ ФІЗИЧНОГО ВИХОВАННЯ СТУДЕНТІВ У ЗАКЛАДАХ ВИЩОЇ ОСВІТИ
}

\begin{abstract}
Mета дослідження - проаналізувати ступінь вивчення проблеми використання секційної моделі організації фрізичного виховання студентів у закладах вищої освіти. Методи дослідження: узагальнення літератури й матеріалів мережі Інтернет, абстрагування, аналіз, синтез. У статті подано результати аналізу особливостей реалізації секційної моделі організації фізичного виховання студентів у закладах вищої освіти. Вони полягають у використанні найбільш популярних $i$, одночасно, досяжних із точки зору матеріально-технічного забезпеченя видів спорту в процесі секційних занять. Основною проблемою реалізації секційної моделі $\epsilon$ матеріально-технічне забезпечення та необхідність якісної підготовки викладачів фізичного виховання для закладів вищої освіти.
\end{abstract}

Ключові слова: фрізичне виховання, студенти, заклади вищої освіти, секційна (спортивно орієнтована) модель.

Постановка проблеми. У наш час процес фізичного виховання студентства в закладах вищої освіти переживає значні трансформації, що частково зумовлене входженням України в європейський освітній простір. Поряд із багатьма його позитивними моментами, $\epsilon$ ті, що потребують удосконалення. На думку Т. Ю.Круцевич і О.Ю. Марченко (Круцевич, Марченко, 2008) є необхідність надавати учням можливість вільного самовизначення та вибору виду фізичної культури, засобів, методів і форм навчання відповідно до їх уподобань, потреб і мотивів. Поряд із цим, на думку окремих науковців (Стасюк, Востоцкая, Осипова, 2009; Prusik, Krzysztof, Prusik, Katarzyna, Kozina, lermakov, 2013), не завжди враховані ціннісні орієнтації, потреби, інтереси, що складають спрямованість особистості студента, тому процес фізичного виховання у свідомості студентів стає механічною діяльністю, головною метою якого $€$ здача нормативів і отримання заліку. 
У якості основних вимог до розробки моделей організації фізичного виховання науковці (Ольховий, 2014; Пилипей, 2008; Салатенко, 2012) вбачають задоволення мотиваційних пріоритетів студентів; забезпечення оптимального режиму їх рухової активності; урахування кадрових i матеріально-технічних можливостей закладів освіти.

3 метою забезпечення викладання фізичного виховання в закладах вищої освіти на належному рівні МОН України розроблено «Рекомендації щодо організації фізичного виховання у вищих навчальних закладах», оприлюднені листом від 25.09.2015 № 1/9-454 [40], де запропоновано кілька базових моделей організації фізичного виховання або різних форм їх поєднання: секційну (створення широкої мережі як спеціалізованих спортивних, так і загальнооздоровчих секцій, гуртків, клубів, які працюють за фіксованим розкладом); професійно орієнтовану (прямо орієнтовану на особливості майбутньої професії); традиційну та індивідуальну (закріплення за кожним студентом працівника кафедри фізичного виховання або спортклубу).

У нашому розумінні найбільш перспективними з цих моделей $\epsilon$ секційна та професійно орієнтована, оскільки вони досить реалістично можуть бути забезпечені ресурсами й кадрами закладів освіти. Вони доволі широко представлені в наукових дослідженнях в Україні (Пилипей, 2008; Салатенко, 2012) і за кордоном (Prusik, Krzysztof, Prusik, Katarzyna, Kozina, lermakov, 2013).

Але в сучасних умовах для реалізації секційної (спортивно орієнтованої) моделі набуває особливого значення поєднане врахування результуючих показників формування фізичної культури особистості 3 максимально точним підбором видів спорту для організації секцій відповідно до побажань студентів, кадрових і матеріально-технічних можливостей закладів освіти. Тому існує проблема необхідності вдосконалення секційної моделі організації фізичного виховання студентів із підбором найбільш популярних у конкретному регіоні видів спорту, зумовлена недостатнім рівнем теоретико-методичної розробленості даного питання та нагальною потребою в практичному впровадженні відповідних наукових результатів.

Аналіз актуальних досліджень. У науковій літературі знаходимо низку досліджень, присвячених проблемі фізичного виховання студентів закладів вищої освіти різних типів, а саме - педагогічних (О. Романчишин (Романчишин, Сидорко, Андрес, 2009; Романчишин, Сидорко, Дика, 2010); Н. Криворучко (Криворучко, 2015); О. Ландо (Ландо, 2014); Л. Крошки (Крошка, Борисенко, 2016; Крошка, 2018; Крошка, Варфоломєєва, 2015)), гірничих (А. Чопова та В. Міщенко (Міщенко, Чомпова, 2016)), медичних (Н. Семенова, А. Магльований (Семенова, Магльований, 2012); І. Шостак, С. Кузякіна та О. Письменна (Шостак, 2014)), будівельних (М. Мамешина та 
Д. Гузієватий (Мамешина, Гузієватий, 2016)), коледжів різного профілю спеціальностей (С. Трачук, Т. Імас та Л. Кузнецова (Трачук, Імас, Кузнецова, 2015); Т. Круцевич (Круцевич, Трачук, Кузнецова, 2016)), технічних (В. Хомич (Хомич, 2007)), у тому числі із застосуванням інноваційних технологій (Р. Зоря (Зоря, 2015); С. Крошка, К. Варфоломєєва (Крошка, Варфоломєєва, 2015)).

Також у сучасній науці активізуються дослідження, присвячені питанню застосування засобів із різних видів спорту в процесі фізичного виховання студентів, зокрема настільного тенісу (О. Коломійцева та Я. Радченко (Коломійцева, Радченко, 2012)), карате-до шотокан (О. Лукіна зі співавторами (Лукіна, Кусовська, Барабаш, 2018)), бадмінтону (С. Крошка (Крошка, 2018)), пауерліфтингу - Н. Бачинська (Бачинська, 2014); Р. Власенко (Власенко, Зозуля, 2014); В. Жамардій (Жамардій, 2013; Жамардій, 2014); С. Женьцян (Женьцян, 2015); І. Мичка (Мичка, 2015), Н. Завидівська (Завидівська, 2017), Ю. Гордієнко (Гордієнко, 2010), Г. П. Грибан (Грибан, Мичка, 2018), хортингу С. Закопайло (Закопайло, 2018), плавання - Ю. Журавльов (Журавльов, Маліков, 2019), баскетболу - А. Кашуба (Кашуба, Ковальський, 2018), військово-спортивного багатоборства - О. Хоменко (Хоменко, Рибалко, 2018).

Мета дослідження: проаналізувати ступінь дослідженості проблеми використання секційної моделі організації фізичного виховання студентів у закладах вищої освіти.

Методи дослідження: узагальнення літератури й матеріалів мережі Інтернет, абстрагування, аналіз і синтез.

Виклад основного матеріалу. Питання щодо організації фізичного виховання студентів закладів вищої освіти різних рівнів акредитації в процесі навчальних та позанавчальних занять $€$ недостатньо вивченим, i вимагає проведення спеціальних досліджень. Зокрема, недостатньо досліджено проблему застосування секційної (спортивно орієнтованої) моделі організації фізичного виховання, у тому числі, конкретних видів спорту, які можуть бути використані для розв'язання завдань фізичного виховання. Недостатньо досліджена проблема визначення перспектив застосування різних видів рухової активності, у тому числі, конкретних видів фізичних вправ, які забезпечують раціональні режими для конкретного профілю спеціальностей (Трачук, Імас, Кузнецова, 2015).

Основними завданнями фізичного виховання молоді в системі освіти має бути формування потреби в зміцненні здоров'я засобами фізичної культури та спорту; збільшення обсягу рухової активності залежно від психофізіологічної потреби в рухах; підвищення якості навчального процесу 3 фізичного виховання та забезпечення його висококваліфікованими кадрами, сучасними науково-методичними комплексами й відповідним матеріально-технічним оснащенням; оптимізація управління у цій сфері тощо (Нейман, 2015). 
Важлива роль сучасного закладу освіти щодо забезпечення здоров'я студента зумовлена також особливостями його функціонування як цілісної багаторівневої системи, що впродовж тривалого часу істотно впливає на психічний і фізичний розвиток особистості (Профессійна підготовка фрахівців щодо створення здоров'язбережувального освітнього простору). Звичайно, у даному контексті важливо говорити про особливості організації процесу фізичного виховання в коледжах та університетах.

В. Міщенко та А. Чомпова провели дослідження стосовно мотивації студентів коледжів до занять фізичною культурою та спортом (на базі гірничого коледжу ДВНЗ «КНУ») (Міщенко, Чомпова, 2016). Надзвичайно цікавим, на нашу думку, є той факт, що за даними науковців студенти вважають головним мотивом до занять фізичною культурою та спортом підвищення фізичної підготовленості.

За даними С. Кузякіної та О. Письменної (Професійна підготовка фрахівців щодо створення здоров'язбережувального освітнього простору), більшість студентів коледжу не прагнуть до досягнення високих спортивних результатів, а у своїх заняттях фізичними вправами керуються мотивами щодо зміцнення здоров'я, стати більш сильними, спритними, витривалими, мати красиву фігуру.

Таким чином, здійснивши аналіз сучасних наукових досліджень стосовно мотивації студентів закладів вищої освіти до занять фізичною культурою та спортом можна зробити висновок, що для молоді, здебільшого, основним стимулом є відвідування обов'язкових занять фізичною культурою, а також фізкультурно-оздоровчих заходів і спортивних змагань.

Важливими, на нашу думку, є методичні рекомендації дослідників (Міщенко, Чомпова, 2016; Професійна підготовка фрахівців щодо створення здоров'язбережувального освітнього простору; Шостак, 2014) стосовно підвищення мотивації студентів до рухової активності: відкриття секцій із популярних видів спорту; коригування навчальних програм; планування освітнього процесу з урахуванням мотивів та інтересів студентів; покращення матеріально-технічної бази; організація дозвілля в позанавчальний час у вигляді спортивних змагань, заходів, свят, спортивно-масових заходів тощо.

С. Трачук зі співавторами (Трачук, Імас, Кузнецова, 2015) зазначають, що питання вивчення фізичної підготовленості студентів ЗВО різного профілю спеціальностей у процесі навчальних занять із фізичної культури $\epsilon$ недостатньо вивченим і вимагає проведення спеціальних досліджень. Зокрема, як наголошують науковці, недостатньо досліджено проблеми визначення перспектив застосування різних видів рухової активності, у тому числі, конкретних видів фізичних вправ, які забезпечують раціональні режими для конкретного профілю спеціальностей закладів вищої освіти.

Науковці (Семенова, Магльований, 2012), спираючись на «Глобальні рекомендації з фізичної активності для здоров'я» (2010р.), розробили такі 
вказівки з їі забезпечення: діти й молоді люди віком 5-17 років повинні займатися щодня фізичною активністю від помірної до високої інтенсивності, в цілому, не менше ніж 60 хвилин; фізична активність тривалістю більше ніж 60 хвилин на день буде корисною для їх здоров'я; велика частина щоденної фізичної активності повинна припадати на аеробіку; фізична активність високої інтенсивності, включаючи вправи з розвитку скелетно-м'язових тканин, повинна проводитися, як мінімум, три рази на тиждень.

О. Романчишин зі співавторами звертають особливу увагу на те, що за останні роки зареєстровано погіршення загальної фізичної працездатності студентів із роками навчання у вищому навчальному закладі (Романчишин, Сидорко, Андрес, 2009; Романчишин, Сидорко, Дика, 2010). Також спостерігається зниження рівня аеробної продуктивності та зростання ступеня функціонального напруження серцево-судинної системи організму студентів. При цьому встановлена істотна різниця у функціональному стані представників різних вікових груп. Найбільш сприятливі значення даних показників відзначаються в студентів і студенток I та II курсів, а найменш оптимальні в представників старших курсів. Для дівчат ще й притаманна більш рання стадія суттєвого зниження абсолютних значень загального функціонального стану організму.

Важливими в даному контексті є висновки науковців (Круцевич, Трачук, Кузнецова, 2016) про те, що дані стосовно рівня фізичної підготовленості студентів коледжів різних спеціальностей визначають особливості прояву їх фізичних здібностей, що визначає безпосередню ясність стосовно планування й організації процесу фізичного виховання у ЗВО та забезпечує основу цього успіху в подальшій виробничій діяльності майбутніх фахівців галузей.

Варто зазначити, що, за даними науковців (Професійна підготовка фахівців щодо створення здоров'язбережувального освітнього простору), причини зростання захворюваності студентів пов'язуються й $з$ недоліками в системі вищої освіти, з тими чинниками навчальної діяльності, які призводять до перенапруження нервової системи й заважають створенню належних умов для задоволення потреб у самопізнанні, самовдосконаленні й самореалізації. Через навчальні перевантаження більшість студентів страждає від недостатньої активності

За даними Ю. Коваленка, процес фізичного виховання в навчальновиховних закладах типу ліцеїв реалізується ще за традиційними підходами без використання інноваційних технологій у професійно-прикладній фізичній підготовці, що не сприяє якості навчання й виховання стійкої мотивації до здорового способу життя (Коваленко, 2014).

Цінними в даному контексті $€$ висновки науковців (Профресійна підготовка фрахівців щодо створення здоров'язбережувального освітнього простору) стосовно того, що інноваційні 
здоров'язбережувальні технології навчання й виховання студентів мають забезпечити високий рівень психосоматичного здоров'я, розумової працездатності, формувати мотивацію до ведення здорового способу життя та виховувати високу культуру здоров'я.

Таким чином, використання інноваційних форм і методів роботи на заняттях дозволить не лише підвищити інтерес студентів до вивчення фізичної культури, але й удосконалити ефективність уже набутих знань.

Ю. Коваленко звертає увагу на питання оптимізації фізичного виховання учнів ліцею з використанням засобів рукопашного бою (Коваленко, 2014). Дослідження, в якому взяло участь 17 юнаків 16-17 років, показало, що цей вид спорту позитивно впливає на функціональні показники показники студентів. Автор також зазначає, що прикладна фізична підготовка в ліцеях поряд із вирішенням основних завдань фізичного виховання повинна забезпечувати якісну підготовку ліцеїстів до навчання в закладах вищої освіти Єдиної системи військової освіти, виховання в них вольових і командирських навичок та якостей.

Н. Криворучко в наукових дослідженнях акцентує увагу на застосуванні чирлідингу у фізичному вихованні студенток 3ВО І-ІІ рівня акредитації (Криворучко, 2015). Чирлідинг, за даними науковця, містить широкий арсенал різноманітних інтенсивних рухів, сприяє зміцненню фізичних і духовних сил, вихованню естетичного смаку, формуванню інтересу до здорового способу життя та підвищенню рівня фізичного розвитку підлітків. У дослідженні взяло участь 385 студенток I-III курсів нефізкультурного профілю. Результати експерименту показали, що впровадження в процес фізичного виховання вправ чирлідингу сприяло підвищенню рівня фізичного розвитку студенток за показниками функціонування дихальної системи.

В. Жамардій розробив модель формування спеціальних умінь і навичок студентів закладів вищої освіти в процесі занять із пауерліфтингу. Завданнями навчальних занять за розробленою моделлю було засвоєння системи наукових знань, формування спеціальних умінь і навичок, світогляду, моральних поглядів і переконань, ідеалів, потреб, цінностей, способів поведінки та діяльності, підбір навантаження різної спрямованості залежно від обсягу та інтенсивності фізичних навантажень (Жамардій, 2014).

C. Женьцян запропонував оздоровчу методику занять пауерліфтингом для студентів університетів з ураженнями опорнорухового апарату для позааудиторних занять від першого до п'ятого курсів. Використання методики, за висновками дослідника, сприяє постійному вдосконаленню рухових якостей і навичок, поліпшенню нейродинамічних властивостей вищої нервової діяльності (Женьцян, 2015).

Важливим засобом, що сприяє оптимізації фізичного виховання студентів коледжів, С. Крошка називає бадмінтон (Крошка, Борисенко, 2016; Крошка, 2018; Крошка, Варфоломєєва, 2015). Дослідницею розроблено й 
впроваджено в практику фізичного виховання студентів методичні рекомендації та практичного курсу «Бадмінтон - запорука здоров'ю» 3 проведення занять із фізичної культури з використанням елементів бадмінтону, практичних рекомендацій для спрямованого розвитку фізичних якостей.

Програма, розроблена С.Крошкою, складається 3 таких розділів: пояснювальна записка, мета й завдання, розподіл годин програмного теоретичного та практичного матеріалу, види й методи педагогічного контролю. Теоретичний і практичний матеріал було представлено у вигляді модулів (теоретичного, діагностичного, рекреаційного, профілактичного, змагального). Також розроблено й запропоновано до впровадження варіативну систему педагогічного контролю - комплекс заходів, що забезпечують перевірку запланованих показників фізичного виховання для оцінки застосовуваних засобів, методів і навантажень. Метою педагогічного контролю в процесі позакласних занять було визначення зв'язків між чинниками впливу й тими змінами, які відбуваються в студентів у процесі занять (Крошка, 2018).

В іншому науковому дослідженні С. Крошки разом з Л. Борисенком (Крошка, Борисенко, 2016) розглянуто діяльність спортивного клубу Лисичанського педагогічного коледжу як самостійної фізкультурноспортивної організації, визначається його роль у зміцненні здоров'я студентів. Досвід роботи названого клубу можна застосувати в діяльності інших коледжів. Тому вважаємо за необхідне зазначити основні завдання роботи спортивного клубу (за Л. Борисенком та С. Крошкою) (Крошка, Борисенко, 2016): створення відповідних умов і можливостей для задоволення різнобічних інтересів студентів, працівників та інших осіб у сфері фізичної культури та спорту; формування всебічно розвиненої особистості члена клубу засобами фізичної культури та спорту; сприяння здійсненню заходів щодо створення та зміцнення спортивної бази клубу й ефективного їі використання; забезпечення виконання комплексних і цільових програм із питань фізкультурно-реабілітаційної та спортивної роботи в навчально-виховній сфері; пропаганда здорового способу життя, запровадження фізичної культури та спорту в систему навчання, роботи, побуту й відпочинку студентів і співробітників коледжу; використання засобів фізичної культури та спорту для професійно-прикладної підготовки студентів як майбутніх фахівців сфери виробництва; організація та проведення масових фізкультурно-оздоровчих і спортивних заходів, надання послуг у сфері фізичної культури і спорту; створення фізкультурно-спортивних аматорських об'єднань, секцій, команд із різних видів спорту, спортивних шкіл різного профілю; проведення роботи щодо спортивного вдосконалення студентів, підготовки й відрядження збірних команд коледжу на змагання різного рівня.

у літературі здебільшого знаходимо дослідження, присвячені організації секційних занять у закладах вищої освіти III-IV рівнів 
акредитації - із гімнастики (А. Дяченко, 2014), шейпінгу (А. Косівська, 2015), фітнесу (А. Гурєєва зі співавторами, 2017), плавання (Ю. Журавльов, 2019), спортивних ігор - баскетболу, волейболу, тенісу, футболу, бадмінтону (І. Чередніченко, 2016; А. Кашуба, 2018; К. Загородній, 2018), військовоспортивного багатоборства (О. Хоменко, П. Рибалко, 2018) та ін.

На нашу думку, варто визначити переваги секційних занять над звичайними заняттями з фізичного виховання. Як зазначають Т. Маленюк та А. Косівська, академічні заняття з фізичного виховання не задовольняють потреби молоді й мають спрямованість на загальну фізичну підготовку в традиційних видах спорту. Натомість, секційні заняття дають змогу студентам самостійно обирати вид спорту, в якому вони бажають самовдосконалюватися, випробовувати себе в новій справі, а викладачів стимулюють до вивчення нових течій у професійній сфері. Секційна форма організації занять сприяє підвищенню мотивації студентів до занять за рахунок теоретичної, методичної, фізичної та функціональної підготовки студентів у нетрадиційних видах рухової активності.

Л. Дудорова вважає, що секційні заняття в позанавчальний час дозволяють збільшити загальний час занять фізичними вправами й у сукупності 3 навчальними занятями забезпечують оптимальну безперервність і ефективність фізичного виховання студентів у ЗВО (Крошка, Варфоломєєва, 2015). Однак, як наголошує дослідниця, незважаючи на всі позитивні сторони використання секційних занять із метою підвищення рівня фізичної підготовленості студентів, постає низка питань, які вказують на відсутність чіткої концепції організації цих занять, щодо їх диференціації відносно здібностей та уподобань студентів.

Ми вважаємо, що визначення мотивації студентів до занять обраним видом спорту $\epsilon$ важливою умовою правильної та чіткої організації секційних занять.

Розглянемо наукові праці, у яких досліджується проблема організації секційних занять у коледжах. У науковій розвідці О. Дяченко та В. Теслюк представлено особливості виховання студентської молоді в агротехнічному коледжі (Круцевич, Марченко, 2008). Як зазначають науковці, на території коледжу, викладачами циклової комісії фізичного виховання та захисту Вітчизни організовані й функціонують клуб «Патріот» та секція з кульової стрільби.

Кожного року до Дня партизанської слави проводяться виховні години на теми: «Партизанський рух на Київщині», «Стежками партизанської слави», «Бородянщина партизанська», до дня захисника Вітчизни «Батьківщина - рідна мати, нам ії і захищати» тощо. У коледжі створені всі сприятливі умови для занять фізичною культурою та спортом, втілюється програма «Здоров'я молоді - здоров'я нації». У позааудиторний час студенти мають змогу займатись у 12 спортивних секціях: волейболу, 
баскетболу, тенісу, футболу, легкої атлетики, вільної боротьби, гирьового спорту, шахів (Круцевич, Марченко, 2008).

У дослідженні О. Коломійцевої та Я. Радченка представлено інформацію про організацію та проведення секційних занять настільним тенісом (Коломійцева, Радченко, 2012). Таким чином, науковці доповнили дані Л. Сергієнка стосовно розвитку координаційних здібностей студентів коледжу. Так, за їхніми висновками, як юнаки, так і дівчата 15 та 16 років показують результати, відповідні «низькому рівню». Також автори наголошують, що координаційні здібності юнаків та дівчат 15-16 років, які розпочали заняття настільним тенісом, знаходяться на середньому рівні. У статевому аспекті в прояві здатності до орієнтування в просторі й утримання статичної рівноваги помітна перевага дівчат над юнаками. У здатності до управління рухами за просторово-часовими та динамічними параметрами результати юнаків домінують над даними дівчат (Коломійцева, Радченко, 2012).

\section{Висновки та перспективи подальших наукових розвідок.}

1. Проблема реалізації секційної моделі організації фізичного виховання на основі занять із різних видів спорту для студентів III-IV рівнів акредитації висвітлена не повною мірою. Здебільшого це питання дослідниками висвітлюється для студентів I-II рівнів акредитації.

2. Основний фокус у розв'язанні проблеми реалізації секційної моделі організації фізичного виховання студентів автори рекомендують зробити на використанні найбільш популярних і, одночасно, досяжних із точки зору матеріально-технічного забезпеченя видів спорту в процесі секційних занять. Для цього здебільшо використовуються: баскетбол, волейбол, плавання, настільний теніс, футбол, легка атлетика та інші види.

3. Основною проблемою реалізації секційної моделі є матеріальнотехнічне забезпечення та необхідність якісної підготовки викладачів фізичного виховання для закладів вищої освіти.

Перспектива подальших досліджень пов'язана з вивченням особливостей реалізації професійно орієнтованої та індивідуальної моделей організації фізичного виховання студентів, розробкою та експериментальною перевіркою секційної моделі в умовах регіону.

\section{ЛІТЕРАТУРА}

Бачинська, Н. В. (2014). Особливості розвитку силових якостей у студентів на заняттях $з$ фізичного виховання на прикладі пауерліфтингу Актуальні питання освіти, спорту та здоров'я у вищих навчальних закладах, 8-14. (Bachinskaya, N. V. (2014). Features of development of power qualities in students in physical education classes on the example of powerlifting. Topical issues of education, sports and health in higher educational establishments, 8-14.).

Власенко, Р. П., Зозуля, А. М. (2014). Розвиток сили в умовах спортивного тренування 3 пауерліфтингу. Біологічні дослідження, 1, 467-469. (Vlasenko, R. P., Zozulya, A. M. (2014). Development of strength in conditions of sports training in powerlifting. Biological Research, 1, 467-469.). 
Гордієнко, Ю. В. (2010). Самоаналіз фізіологічних особливостей організму жінок, які спеціалізуються в пауерліфтингу. Педагогіка, психологія та медико-біологічні проблеми фрізичного виховання і спорту, 1, 43-46. (Gordienko, Yu. V. (2010). Selfexamination of physiological features of the body of women who specialize in powerlifting. Pedagogics, Psychology, Medical-Biological Problems of Physical Training and Sports, 1, 43-46).

Грибан, Г. П., Мичка, І. В. (2018). Педагогічні засади навчання силових вправ 3 пауерліфтингу студентської молоді в освітньому процесі з фізичного виховання. Вісник Кам'янець-Подільського національного університету імені Івана Огієнка, 11, 102-110. (Griban, G. P., M ichka, I. V. (2018). Pedagogical principles of powerlifting training for student youth powerlifting in the physical education education process. Bulletin of Kamyanets-Podilskyi Ivan Ogiyenko National University, 11, 102-110).

Жамардій, В. О. (2013). Критерії та рівні формування спеціальних умінь і навичок студентів вищих навчальних закладів у процесі занять з пауерліфтингу. Витоки педагогічної майстерності, 11, 130-135. (Samardiy, V. O. (2013). Criteria and levels of development of special skills of students of higher education in the process of powerlifting classes. Origins of Pedagogical Skills, 11, 130-135).

Жамардій, В. О. (2014). Модель формування спеціальних умінь і навичок студентів вищих навчальних закладів у процесі занять 3 пауерліфтингу. Витоки педагогічної майстерності, 13, 120-127. (Samardiy, V. 0. (2014). Model of formation of special skills of students of higher education in the process of powerlifting lessons. Origins of Pedagogical Excellence, 13, 120-127).

Женьцян, С. (2015). Методика удосконалення рухових якостей і функціональної підготовленості студентів університетів з ураженнями опорно-рухового апарату на заняттях з пауерліфтингу (дис. ... канд. наук з фіз. виховання i спорту: 24.00.02). Харків. (Zhenqiang, S. Methods of improving the motor qualities and functional preparedness of university students with musculoskeletal disorders in powerlifting classes (PhD thesis). Kharkiv).

Журавльов, Ю., Маліков, М. (2019). Ефективність використання засобів аквааеробіки у процесі секційних занять з плавання студентів 18-19 років. Слобожанський науково-спортивний вісник, 2, 59-63. (Zhuravlev, Y., Malikov, M. (2019). Efficiency of use of aqua aerobics means in the process of section classes for swimming of students of 18-19 years. Slobozhansk Scientific and Sport Bulletin, 2, 59-63).

Закопайло, С. (2018). Вплив секційних занять з хортингу на фізичну підготовленість старшокласників. Спортивний вісник Придніпров'я, 1, 126-130. (Zakopaylo, S. (2018). Influence of section classes on horting on physical fitness of high school students. Prydniprovsky Sports Newsletter, 1, 126-130).

Завидівська, Н. Н. (2017). Стан методичного забезпечення занять пауерліфтингом як змісту фізичної активності студенток вищих навчальних закладів. Молодіжний науковий вісник Східноєвропейського начіонального університету імені Лесі Українки, 27, 38-42. (Zavidovskaya, N.N. (2017). The state of methodical provision of powerlifting as a content of physical activity of female students of higher educational establishments. Youth Scientific Bulletin of Lesya Ukrainka Eastern European National University, 27, 38-42).

Зоря, Р. Р. (2015). Використання інформаційних технологій при викладанні дисципліни «Безпека життєдіяльності». "Інноваційний потенціал світової науки - XXI cmоріччя», 12-13. (Zoria, R. R. (2015). Use of information technologies in teaching the subject "Safety of life", "Innovative potential of world science - XXI century". 12-13). 
Кашуба, А., Ковальський, В. (2018). Динаміка показників фізичної підготовленості студентів першого року навчання під впливом секційних занять з баскетболу. Актуальні проблеми фрізичного виховання та методики спортивного тренування, 2, 21-25. (Kashuba, A., Kovalsky, V. (2018). Dynamics of physical fitness indicators of students of the first year of study under the influence of section basketball lessons. Actual Problems of Physical Education and Methods of Sports Training, 2, 21-25).

Коваленко, Ю. О. (2014). Оптимізація фізичного виховання учнів ліцею з використанням засобів рукопашного бою. Вісник Запорізького національного університету, 1, 2835. (Kovalenko, Y. O. (2014). Optimization of physical education of Lyceum students using hand-to-hand combat. Bulletin of Zaporizhzhya National University, 1, 28-35).

Коломійцева, О., Радченко, Я. (2012). Настільний теніс як засіб розвитку координаційних здібностей студентів коледжу. Слобожанський науковоспортивний вісник, 5, 16-19. (Kolomiytseva, O., Radchenko, E. (2012). Table tennis as a mean of developing the coordination skills of college students. Slobozhansky Scientific and Sport Bulletin, 5, 16-19).

Криворучко, Н. (2015). Вплив вправ чирлідингу на показники фізичного розвитку студенток ВНЗ І-ІІ рівня акредитації. Молода спортивна наука України, 19, 119124. (Krivoruchko, N. (2015). Influence of cheerleading exercises on indicators of physical development of university students of I-II level of accreditation. Young Sports Science of Ukraine, 19, 119-124).

Крошка, С. А., Борисенко, Л. Л. (2016). Спортивний клуб Лисичанського педагогічного коледжу - самостійна фізкультурно-спортивна організація. Virtus: Scientific Journal, 8, 82-86. (Kroshka, S. A., Borisenko, L. L. (2016). Lysychansk Pedagogical College Sports Club is an independent physical and sports organization. Virtus: Scientific Journal, 8, 82-86).

Крошка, С. А. (2018). Методична розробка та впровадження практичного курсу «Бадмінтон - запорука здоров'ю» для студентської молоді. Спортивні ігри, 3, 25-34. (Kroshka, S. A. (2018). M ethodical development and implementation of a Badminton - a pledge of health practical course for student youth. Sports Games, 3, 25-34).

Крошка, С. А., Варфоломєєва, К. (2015). Інноваційні технології з фізичного виховання у Лисичанському педагогічному коледжі. Молодь, освіта, наука, культура $i$ національна самосвідомість в умовах європейської інтеграції. 1, 106-109. (Kroshka, S. A., Varfolomeeva, K. (2015). Innovative technologies in physical education in Lisichanski Pedagogical College. Youth, education, science, culture and national consciousness in the context of European integration, 1, 106-109).

Круцевич, Т. Ю., Марченко, О. Ю. (2008). Спрямованість цінностей індивідуальної фізичної культури студентів різних відділень вузу. Спортивний вісник Придніпров'я, 3-4, 103-107. (Krutsevich, T. Yu., Marchenko, O. Yu. (2008). Orientation of values of individual physical culture of students of different branches of the university. Prydniprovsky Sports Newsletter, 3-4, 103-107).

Круцевич, Т. Ю., Трачук, С. В., Кузнецова, Л. І. (2016). Фізична підготовленість юнаків коледжів різних спеціальностей. Вісник Чернігівського начіонального педагогічного університету, 136, 115-119. (Krutsevich, T. Yu., Trachuk, S.V., Kuznetsova, L.I. (2016). Physical fitness of college youth of different specialties. Bulletin of the Chernihiv National Pedagogical University, 136, 115-119).

Ландо, О. А. (2014). Використання здоров'язбережних технологій у навчальновиховному процесі педагогічного коледжу. Педагогіка формування творчої особистості у вищій і загальноосвітній школах, 37, 247-254. (Lando, O. А. 
(2014). The use of health and technology in the educational process of the College of Education. Pedagogy of Creating a Creative Personality in Higher and Secondary Schools, 37, 247-254).

Лукіна, О., Кусовська, О., Барабаш, К. (2018). Особливості розвитку фізичних якостей студенток музичного коледжу засобами карате-до шотокан, The Caucasus. Economic and Social Analysis Journal of Southern Caucasus, 6(27), 37-39. (Lukina, O., Kusovska, O., Barabash, K. (2018). Features of development of physical qualities of students of music college by means of karate-do Shotokan, The Caucasus. Economic and Social Analysis J ournal of Southern Caucasus, 6(27), 37-39).

Мамешина, М. А., Гузієватий, Д. В. (2016). Фізичне здоров'я студентів ВНЗ І-ІІ рівня акредитації. Актуальні проблеми фрізичного виховання різних верств населення, 100-108. (M ameshina, M.A., Guziyatiy, D.V. (2016). Physical health of students of I-II level of accreditation. Actual problems of physical education of different groups of the population, 100-108).

Мичка, І. В. (2015). Побудова тренувального процесу з пауерліфтингу на етапі початкової підготовки. Фізичне виховання та спорт у контексті державної програми розвитку фізичної культури в Україні, 2, 45-47. (Michka, I.V. (2015). Building a powerlifting training process in the initial training phase. Physical Education and Sport in the Context of the State Program of Physical Culture Development in Ukraine, 2, 45-47).

Міщенко, В. Л., Чомпова, А. П. (2016). Мотивація студентів ГК ДВНЗ «КНУ» до занять фізичним вихованням під час навчання у навчальному закладі. «Потенціал дисципліни «Фізичне виховання» у закладах освіти», 13-116. (M ishchenko, V.L., Chompova, A.P. (2016). M otivation of students of GK DVNZ "KNU" to take physical education while studying in an educational institution. "The potential of discipline" physical education "in educational institutions", 13-116).

Нейман, А. В. (2015). Ціннісні орієнтації до занять фізичною культурою студентів педагогічних коледжів як стимул до здорового способу життя, Молодь та Олімпійський рух, 314-316. (Neumann, A. W. (2015). Value orientations to physical education of students of pedagogical colleges as an incentive to a healthy lifestyle. Youth and Olympic M ovement, 314-316).

Олешко, В. Г. (1999). Силові види спорту. К.: Олімпійська література (Oleshko, V. G. (1999). Power sports. K.: Olympic literature).

Ольховий, О. М. (2014). Стан функціонування системи фізичного виховання закладів вищої освіти. Теорія і методика фізичного виховання і спорту, 2, 79 - 83. (Olkhovyi, O. M. (2014). The state of functioning of the system of physical education of institutions of higher education. Theory and methodic of physical education and sport, 2, $79-83$ ).

Пилипей, Л. П. (2008). Професійно-прикладна фізична підготовка студентів. Суми: УАБС НБУ (Pylypey, L. P. (2008). Professionally applied physical training of students. Sumy: UABS NBU).

Профресійна підготовка фрахівців щодо створення здоров'язбережувального освітнього простору. Режим доступу: http:// elar.ippo.edu.te.ua:8080/bitstream/123456789/5366/1/zbirnuk-117-122.pdf (Professional training in creating a health-saving educational space. Retreaved from: http://elar.ippo.edu.te.ua:8080/bitstream/123456789/5366/1/ zbirnuk-117-122.pdf).

Романчишин, О., Сидорко, О., Андрес, А. (2009). Динаміка рівня фізичної підготовленості студентів педагогічного коледжу. Молода спортивна наука України, 2, 154-160. (Romanchishin, 0., Sidorko, O., Andres, A. (2009). Dynamics of 
the level of physical fitness of students of the pedagogical college. Young Sports Science of Ukraine, 2, 154-160).

Романчишин, О., Сидорко, О., Дика, М. (2010). Соматичне здоров'я, адаптаційний потенціал, фізичний стан та біологічний вік студентів педагогічного коледжу. Педагогіка, психологія та медико-біологічні проблеми фрізичного виховання і спорту, 11, 98-101. (Romanchishin, O., Sidorko, O., Dika, M. (2010). Somatic health, adaptation potential, physical condition, and biological age of college students. Pedagogy, Psychology, and Medical-Biological Problems of Physical Education and Sport, 11, 98-101).

Салатенко, І. (2012). Розробка спортивно-орієнтованої технології фізичного виховання для студенток економічних спеціальностей. Молода спортивна наука України, 18 (2), 138-144. (Salatenko, I. (2012). Development of sports-oriented technology of physical education for students of economic specialties. Young Sports Science of Ukraine, 18 (2), 138-144).

Семенова, Н., Магльований, А. (2012). Характеристика рівня добової рухової активності студенток I-II курсів медичного коледжу. Молода спортивна наука України, 16, 136-142. (Semenova, N., Maglovani, A. (2012). Characterization of the level of daily motor activity of the students of the II-II courses of medical college. Young Sports Science of Ukraine, 16, 136-142).

Стасюк, Р. М., Востоцька, І. Ф., Осипова, І. Л. (2009). Проблеми та шляхи підвищення ефективності фізичного виховання ВН3. Педагогіка, психологія та медикобіологічні проблеми фрізичного виховання і спорту, 3, 146-149. (Stasyuk, R. M., Vostotskaya, I. F., Osipova, I. L. (2009). Problems and ways of improving the efficiency of physical education of higher education institutions. Pedagogy, Psychology and M edical-Biological Problems of Physical Education and Sport, 3, 146-149).

Трачук, С., Імас, Т., Кузнецова, Л. (2015). Фізична підготовленість студенток коледжів різного профілю спеціальностей. Спортивний вісник Придніпров'я, 2, 230-234. (Trachuk, S., Imas T., Kuznetsova, L. (2015). Physical fitness of college students with different specialties. Prydniprovsky Sports Newsletter, 2, 230-234).

Хомич, В. М. (2007). Комплексна модель професійно-прикладної фізичної підготовки студентів технічного профілю. Педагогіка, психологія та медико-біологічні проблеми фрізичного виховання і спорту, 2, 142-146. (Khomich, V. М. (2007). Complex model of professionally applied physical training of students of technical profile. Pedagogy, Psychology, and M edical-Biological Problems of Physical Education and Sport, 2, 142-146).

Хоменко, О., Рибалко, П. (2018). Ефективність застосування засобів військовоспортивного багатоборства у фізичному вихованні студентів аграрних спеціальностей. Спортивна наука України, 4, 51-58. (Khomenko, O., Rybalko, P. (2018). The effectiveness of the use of all-sports all-rounder in the physical education of students of agricultural specialties. Sport Science of Ukraine, 4, 51-58).

Шостак, І. (2014). Роль і місце дисципліни фізичне виховання у формуванні мотивації навчальної діяльності студентів медичного коледжу. Наукові записки Кіровоградського державного педагогічного університету імені Володимира Винниченка, 131, 226-229. (Shostak, I. (2014). The role and place of discipline of physical education in the formation of motivation of educational activity of students of medical college. Scientific Notes of Kirovohrad Volodymyr Vinnychenko State Pedagogical University, 131, 226-229).

щодо організації фрізичного виховання у вищих навчальних закладах: Лист МОН України від 25.09.2015. № $1 / 9$ - 454. (On organization of physical Education in higher educational establishments: letter of MES of Ukraine from 25.09.2015). 
Prusik, Krzysztof, Prusik, Katarzyna, Kozina, Zh. L., lermakov, S. S. (2013). Features of physical development, physical preparedness and functional state of boys and girls - students of Polish higher educational establishments. Physical Education of Students, 1, 54-61.

Prykhodko, V., Tomenko, O. (2019). Innovative approach to the strategic management of the Olympic sport reform in Ukraine. Marketing and Management of Innovations, 1, 357366.

\section{PEЗЮME}

Томенко Александр, Матросов Сергей, Яровая Елена. Особенности секционной модели организации физического воспитания студентов высших учебных заведений.

Целью исследования является анализ степени раскрытия проблемы использования секционной модели физического воспитания студентов в заведениях высшего образования. Методы исследования: обобщение литературы и материалов сети Интернет, абстрагирование, анализ, синтез. В статье показаны результаты анализа особенностей модели организации физичесого воспитания студентов в заведениях высшего образования. Они состоят в использовании самых популярных и, в то же время, достижимых с точки зрения материально-технического обеспечения видов спорта во время секционных занятий. Основной проблемой реализации секционной модели является материально-техническое обеспечение и необходимость качественной подготовки преподавателей физкультуры для заведений высшего образования.

Ключевые слова: физическое воспитание, студенты, заведения высшего образования, секционная (спортивно ориентированная) модель.

\section{SUM MARY}

Tomenko Oleksandr, Matrosov Serhii, Yarova Olena. Peculiarities of the sectional model of physical education of students in higher education institutions.

The purpose of the study is to analyze the degree of the problem of using a sectional model of physical education of students in higher education institutions. The methods of theoretical research were used: generalization of literature and materials of Internet, abstraction, analysis, synthesis. The article presents the results of the analysis of the peculiarities of the sectoral model of the organization of physical education of students in higher education institutions. They consist in use of the most popular and, at the same time, reachable from the point of view of logistical security of sports during sectional classes. The main problem of the sectional model implementation is logistical support and the need for qualitative training of teachers of physical education for higher education institutions.

It is noted that basketball, volleyball, swimming, table tennis, football, track and field are mostly used for implementation of the sectional model. It is established that the problem of realization of the sectional model of organization of physical education on the basis of classes in different sports for students of III-IV levels of accreditation is not fully covered. For the most part, this issue is covered by researchers for students of the first and second levels of accreditation. There is a problem of need to improve the sectional model of organization of physical education of students with the selection of the most popular in a specific region of sports, due to the insufficient level of theoretical and methodological elaboration of this issue and the urgent need for practical implementation of relevant scientific results. The prospect of further research is related to the study of the peculiarities of implementation of professionally oriented and individual models of organization of physical education of students, development and experimental verification of the section model.

Key words physical education, students, higher education institutions, sectional (sports oriented) model. 